O.B. Кїно,

кандидат філологічних наук, старший науковий співробітник Інституту філософії імені Г.С.Сковороди НАН України

\title{
ІДЕЯ СУБ'ЄКТИВНОї ДОБИ У СОЦІАЛЬНІЙ ФІЛОСОФІЇ ШРІ АУРОБІНДО
}

Шрі Ауробіндо у праці «Людський цикл» пише про історичну можливість настання у майбутньому так званої Суб’єктивної доби, коли людська душа пробуджується й виходить на перший план не тільки у індивіда, а й у суспільствах. Він описує ознаки настання суб'єктивного віку - це і революційна перебудова у сферах релігії, філософії, науки, мистецтва та суспільства, це і пробудження Індії та Сходу, це нові тенденції у літературі та мистецтві. На наближення нової, Суб'єктивної доби, на його думку, вказує як поява і множення в усьому світі нового психологічного людського типу - сенсуальної людини, так і феномен національного пробудження Ірландії, Індії, Бенгалії, Німеччини та відкриття самого феномену Нації-Душі.

Але перш ніж перейти до аналізу цих ознак настання Суб'єктивної доби, згадаємо й про небезпеки на шляху його становлення, про які пише Шрі Ауробіндо. Це особливо важливо, якщо враховувати, що Шрі Ауробіндо писав статті «Людського циклу» для журналу «Ар'я» у 1916-1918 рр., а потім через 30 років вносив у текст нові правки і коментарі.

Шрі Ауробіндо належав до покоління, яке сформувалося до 1914 p. і для якого $є$ характерним майже беззастережна віра в еволюцію та історичний прогрес [8]. У 1916 р. вийшла книга Бердяєва «Смисл творчості» і можна лише уявити, які б правки вніс у цю працю Бердяєв через 20 років! Тейяр де Шарден теж належить до покоління, сформованого до 1914 р. і звідси, очевидно, випливає психологічне пояснення його еволюційного оптимізму [3]. Коли Шрі Ауробіндо пише про факти, які можуть протистояти новим тенденціям, він, насамперед, звертається до реалій, які постали після I світової війни, тобто до соціалістичних та фашистських державдиктатур. Нові диктаторіальні типи соціальності, до яких може дійти світ, можуть призупинити процес трансформаційних індивідуальних пошуків, відкриття індивідом та нацією себе, насамперед, як 
душевної, психічної реальності, може бути заблокованим. Суспільство, вважає Шрі Ауробіндо, може бути детерміноване жорстким економічним або урядовим соціалізмом, в якому особистість, знову позбавлена свободи, отримає життя та діяльність, детерміновані на кожному кроці і у кожній точці від народження до старості добре відпрацьованим механізмом держави. Початком такого розвитку подій він вважає соціальну еволюцію фашистської Італії, нацистської Німеччини, комуністичної Росії. Якщо б такій устрій поширився на більшість країн, ми, можливо, отримали б (звісно 3 відмінностями), щось подібне до старого азіатського або навіть індійського ладу у суспільстві. «Навіть індійського» для нього означає, очевидно, кастового, бо саме кастовий устрій вирізняє Індію серед традиційних суспільств.

Шрі Ауробіндо пропонує своє тлумачення причин появи тоталітарних тенденцій. Розкріпачена у новий час індивідуальна думка відкриває універсальні закони, насамперед, економічні, соціальні та біологічні, і починає дивитися на індивіда як на побічний продукт дії цих законів, які мають беззастережно управляти ним. Фашизм та комунізм, очевидно, роблять спробу керувати людством відповідно до механізмів цих законів, що й веде до придушення самої індивідуальної свободи [6].

Шрі Ауробіндо не вважає, що Західний світ навіть після II світової війни став вільним від загрози тоталітарних спокус. Він вважає, що досвід Німеччини запліднив весь інший світ, і розгромлена у війнах Німеччина здобула над іншим світом внутрішню перемогу. Це попередження Шрі Ауробіндо тим актуальніше, що він не розглядає вірогідність технологічного контролю над індивідом, який стає актуальним у другій половині XX - початку XXI ст., та можливостей технічної маніпуляції свідомістю.

В.Грушецький у післямові до книги «Троянда Світу» пише, що $з$ праць Вернадського та Тейяра де Шардена $з$ очевидністю випливає схема: геогенез на найвищій своїй фазі передає накопичений імпульс біогенезові, після чого активність тектонічної діяльності різко йде на спад. Біогенез, набуваючи динаміки, породжує буяння форм життя й передає імпульс ноогенезові, різко заспокоюючись та відкликаючи зі сцени життя монстрів (очевидно, йдеться про динозаврів. - O.К.).

Тепер активність зміщується у сферу розумового розвитку, прогресує лише один вид - Людина розумна, і ця людська сфера в 
апогеї повинна породити наступну сходинку - Людину духовну, але замість цього народжує ... багатоманіття мертвих механізмів. Грушецький вважає, що це - очевидний еволюційний збій, який зайвий раз підтверджується антагонізмом техніки і біосфери. Тобто Грушецький, з одного боку, зводить воєдино дві лінії - техноген, як стіна між людиною розумною та людиною духовною, або супраментальною, використовуючи термін Шрі Ауробіндо, i, з іншого боку, - техніка, як стіна між людиною та попередньою життєвою ланкою - біосферою, до знищення якої майже з залізною неуникністю веде гіпертрофія урбаністично-технократичного розвитку. Цей еволюційний збій Грушецький пояснює втратою цілісного уявлення про світ, насамперед, втратою взаємозв'язку з планами буття, які мають досвід переходу з одного рівня на наступний, який він називає тонкоматеріальним.

Цю позицію можна зіставити з поглядами Шрі Ауробіндо, який проголошує необхідність відродження відкритості людини «більш високим планам існування» [6]. Він пише про сприйняття світу та людства як єдиного цілого, вважає людину перехідною істотою, а Суб'єктивний вік - поверненням до контакту з духовними стадіями буття, які зафіксовані у традиції Вед та Упанішад.

Щоправда, Шрі Ауробіндо не присвячує багато уваги феномену техніки, для нього достатньою є констатація тоталітарних загроз. Сатпрем у книзі про Шрі Ауробіндо значно більше пише про проблеми технічної гіпертрофії: «...Всі ці літаки, телефони, телевізори і сила-силенна знарядь і приборів - все це лише милиці, які маскують наше безсилля, більше того, у презирстві до власних природних здібностей ми дійшли того, що з покоління у покоління вони продовжують вироджуватися і все через лінощі та невігластво. Ми забули просту, але фундаментальну істину, що всі наші фантастичні винаходи - це лише матеріальні проекції сил, які існують всередині нас, і якщо їх би там не було, то винаходити було б ні з чого... Доручивши машинам бачити за нас та пересуватися за нас, ми відразу відчуваємо себе безпорадними, якщо їх немає під рукою» [4, 273]. Бердяєв пише, що машина порушує органічний ритм життя і культуротворчості людини. Машина і техніка для нього підривають органічні основи культури, вбивають іï дух. Культура обездушується і переходить у цивілізацію. Якості замінюються кількостями.

Даниїл Андрєєв у «Троянді Світу», на відміну від Грушецького, 
Сатпрема та Бердяєва йде дещо далі у своїх прогнозах. Він зосереджується саме на проблемі поєднання, схрещування двох факторів: тиранічної одноосібної влади та техніки XXI ст. Він пише, що його не дивує, що кожний успіх науки та техніки повертається тепер одним боком проти справжніх інтересів людства. «Двигун внутрішнього згорання, радіо, авіація, атомна енергія - все це б'є одним кінцем по живій плоті народів. Ще більшу загрозу несе розвиток засобів зв'язку та технічні досягнення, що дає можливість поліцейському режимові контролювати інтимне життя та потаємні думки кожного, підводять залізну базу під вампіричні громади диктатур» $[1,9]$.

Мова Андрєєва відрізняється від мови Шрі Ауробіндо, але він теж покладає чималі надії на демократичні тенденції, що сформувалися на Заході. I для Андрєєва наука і техніка є найбільш цікавими, як і для Шрі Ауробіндо і Тейяра саме в аспектах їхніх соціальних вимірів і наслідків.

Отже, доволі цікаво зіставити погляди на роль техніки різних мислителів. Для Грушецького техноген - своєрідний збій на шляху переходу від людини розумної до людини духовної, і він, крім того, поглиблює провалля між ноосферою та біосферою, руйнуючи останню. Врешті-решт він не може не заторкувати й власне ноосферу для Грушецького, як і для Шрі Ауробіндо, людська розумність може втрачати інтенцію до цілісності. Щодо цього варто згадати й погляд Д. Андрєєва на психічні наслідки для людини, яка постійно працює 3 технікою, оскільки ця праця робить людину утилітарною, і вихід мислитель вбачає у певній ізоляції цілісної людської свідомості від обмежених власних сфер, поглинутих технікою.

Бердяєв теж схильний розглядати два аспекти вторгнення техніки і машини у людське життя - 3 одного боку, зміна самого ритму життя і послаблення зв'язків 3 природою [2]. Цей аспект можна зіставити з лінією конфлікту «техносфера-біосфера» у Грушецького. 3 іншого боку, він вважає, що механічність цивілізації суперечить органічності та духовності буття взагалі та культури, зокрема. Тобто для Бердяєва техніка теж впливає на «долішні» відносини людської еволюції - на зв'язок з природою та одночасно - на «горішні» - на зв'язок $з$ культурою та духовними сферами буття. Щоправда, він не обстоює еволюційну парадигму і говорить радше про кризу культури, ніж про вихід на новий еволюційний етап.

Зрештою Сатпрем, однозначно поділяючи еволюціоністські погляди і відзначаючи складнощі технічного поступу, разом 3 тим 
говорить про іманентно-психологічні аспекти науково-технічного поступу. Адже всі технічні прибори - для нього це символічна проекція внутрішніх сил свідомості. Звичайно, він має на увазі такі доконечні для нього та й для йогів аспекти свідомості, як здатність до телепатії, обміну імпатичною інформацією 3 великої відстані, фактор використання енергії свідомості та обміну цією енергією і т.п. Крім того, думку Сатпрема про символічний аспект технічних досягнень щодо людської свідомості можна зіставити 3 вельми специфічними поглядами Шрі Ауробіндо на символічну стадію культури і особливо - 3 концепцією Бердяєва про фундаментальний символізм будь-якої культури.

До речі, серед мислителів духовно-еволюційного напрямку більш оптимістично оцінював технічний етап розвитку цивілізації Тейяр де Шарден. Це й не дивно - він був чи не єдиний серед них вчений-природничник. Сфера ж головних зацікавлень Шрі Ауробіндо, Бердяєва, Сатпрема, Андрєєва, Грушецького - насамперед, гуманітарні питання. Але й Тейяр досить болісно пережив час випробування атомної зброї [5].

Шрі Ауробіндо у своєму описі Віку Індивідуалізму та Розуму дає доволі цікаву версію можливого поширення тоталітаристських тенденцій за межі Італії, Німеччини та Росії. У кінці 40-х років він пише, що все більше й більше націй приймає це начало нового, механічно-етатистського порядку і спротив старого порядку скоріше пасивний, ніж активний. Шрі Ауробіндо відзначає, що країни-переможці Німеччини теж заражені духом етатизму, це, очевидно, стосується комуністичної Росії, але це, на його переконання, стосується і західних країн. Мислитель робить схематичний нарис характерних рис цього нового порядку, який може стати новим варіантом старого азіатського чи старого індійського порядку суспільства. Якщо на місці релігійно-етичної санкції в ньому буде науково-раціональний або натуралістичний мотив, то повноваження, які в Індії належать Брамінській Шастракарі, заступить науковий, адміністративний і економічний експерт.

На місці короля, монарха, який особисто стежить за дотриманням дхармічного порядку, там стоятиме колективістська держава. Замість ієрархічного влаштування класів, кожного зі своїми привілеями та обов'язками, буде запроваджена висхідна рівність виховання та можливостей з майбутнім визначенням функцій експертами, які, на думку Шрі Ауробіндо, повинні будуть знати нас 
краще, ніж ми самі, і обирати для нас роботу і професію.

Одруження, потомство та виховання дитини може бути фіксовано науковим персоналом Держави, як в традиційній Індії Шастрою. Для кожної людини обов'язковою буде тривала стадія праці для Держави, за якою будуть назирати колективістські авторитети, отже спеціальні уповноважені. Можливо, Шрі Ауробіндо, створюючи оригінальну картину відповідностей нового етатизму традиційному азіатському і вужче - індійському суспільству, він передбачає, що після довготривалої праці для Держави індивід дістане звільнення для насолоди відпочинком i, крім того, для особистого самовдосконалення, як у Саніаса-Ашрамах старого Арійського суспільства. Відомо, що в Індії навіть правителі у літньому віці вирушали до лісу і там присвячували себе служінню богові та аскетичним вправам. Втім, проблематичним є мотиваційний момент - навіщо науково-раціональній спільноті може знадобитися подібне, майже релігійне, покликання пенсіонерів?

Але, 3 іншого боку, Шрі Ауробіндо вважає, що жорстокість такої соціальної держави дуже переважала б їі азіатських попередників, оскільки у минулому для бунтарів-новаторів були зроблені дві важливі поступки. Для індивіда це була свобода ранньої Санніаси, відмова від суспільства заради вільного духовного життя, а для групи - свобода створювати під-суспільство, що керується новими релігійними концепціями, як Сикхське або Вішнуїстське.

У цих тезах Шрі Ауробіндо уточнює попередню тезу про особистісне самовдосконалення у соціальній Державі - воно не матиме релігійного характеру. Жодне 3 цих сильних відхилень від норми не змогло б терпіти строго економічне, жорстко наукове та унітарне суспільство. Очевидно також, пише мислитель, що формується фіксована система соціальної моралі та традиції, а також комплекс соціалістичної доктрини, яку не дозволено буде піддавати сумніву практично, а можливо, навіть інтелектуально, оскільки це швидко розхитає або і підірве систему.

Отже, завершує лінію аналогій Шрі Ауробіндо, ми будемо мати новий «типовий» порядок, що швидко скам'яніє через придушення особистої свободи. Шрі Ауробіндо вважає, що цей порядок неодмінно був би знову зруйнований новим індивідуалістичним віком бунту, який грунтувався б на принципах крайнього філософського анархізму.

Отже, розглядається своєрідна регресія до азіатських традицій: 
замість релігії та етики - наука, замість монарха - колективістська держава, замість класів і каст - рівні можливості та жорсткий професійний детермінізм, не релігійне, а етатистське керівництво всіма сімейними відносинами, замість релігійної санніаси - відпочинок або особисте самовдосконалення, замість самітництва і вільного пошуку духовно-релігійних груп - фіксована система соціальної моралі та комплекс соціальної доктрини. Тут цікавою є заміна одноосібної монархії на колективістську державу. Ми вже згадували погляди Д.Андрєєва на тоталітарні перспективи, тож відзначимо, що у цьому пункті він розходиться з баченням Шрі Ауробіндо і вважає, що колективне-олігархічне правління на певному етапі закономірно може змінюватися на одноосібну диктатуру. Андрєєв не наводить прикладів з історії, але їх неважко розшукати - можна згадати про закономірне перетворення першого тріумвірату в Римі на одноосібну диктатуру Цезаря, другого тріумвірату - на імперію Августа, колективної Директорії та влади трьох консулів у пореволюційній Франції на одноосібне правління імператора Наполеона, перетворення колективного керівництва партією у 20-х роках в СРСР на сталінську диктатуру.

Ця остання аналогія $з$ поглядами Андрєєва тим цікавіша, що Шрі Ауробіндо і Сатпрем не лише спиняються на загрозах, які несе людству перехід від Індивідуалістичної доби до Суб'єктивної, а й розглядають можливості, які можуть виникнути і після завершення Суб'єктивної доби, на порозі настання Духовної, або Супраментальної, доби. Це можливість переходу до панування Глобального Розуму - побудови суспільства під керівництвом одного чи декількох Геніїв, здатних до просвітленого, глобального бачення. Для Шрі Ауробіндо і Сатпрема глобальне бачення - це вища форма людського ментального бачення, і створення суспільства, заснованого на цьому принципі, може видатись надзвичайно привабливою перспективою.

Шрі Ауробіндо розглядає й можливість появи сил, які можуть розладнати або трансформувати жорсткі соціальні моделі раніше, ніж вони досягнуть свого загрозливого завершення. Він пише, що у кінці Віку Індивідуалізму та Розуму індивід відкриє загальні закони, які дадуть йому можливість керувати соціальним життям та придушувати саму індивідуальну свободу. Отже, він стверджує, що раціоналістична та фізична наука у своєму розвитку має бути перекрита новим психологічним знанням, яке відкриває нові обрії 
перед людством. Узагальнюючи цю тезу, можна сказати, що прогрес, насамперед, соціальних та економічних наук, 3 точки зору Шрі Ауробіндо, несе загрозу тоталітаризму, а розвиток психологічного знання підштовхує колективний розум людства у бік актуалізації ідей Суб'єктивної доби. Доба Розуму, вважає Шрі Ауробіндо, помітно сходить до завершення, а нові ідеї є спонтанно згубними для будь-якого передчасного «типового» порядку економічного раціоналізму. Для мислителя - це, насамперед, ніцшеанська воля жити, бергсонівське піднесення інтуїції над інтелектом та певні тенденції у новітній німецькій філософії. До цих тенденцій нової Суб’єктивної доби Шрі Ауробіндо відносить і нові віталістичні тенденції у літературі та відкриття феномену Нації-Душі. Загалом він вважає, що ми, можливо, перебуваємо у ранішніх сутінках нового людського циклу.

Для сучасного дослідника проблема, звичайно, полягає у тому, що ці ранішні сутінки за 70-90 років, що минули з часу написання і повторного редагування «Людського циклу», так і не перетворились на Світанок Суб'єктивної доби, отже, треба говорити або про певні методологічні помилки у концепції Шрі Ауробіндо, або, погоджуючись $з$ його концепцією, вважати, що певні тенденції до перетворення Індивідуалістичної доби на добу Економічного Раціоналізму взяли гору над більш одухотвореними перспективами становлення людства.

\section{ЛІТЕРАТУРА}

1. Андреев Д.Л. Роза мира. Метафилософия истории. - М., 1991.

2. Бердяев Н.А. Смысл истории. - М., 1990.

3. П.Тейяр де Шарден. Феномен человека. - М., 1987.

4. Сатпрем. Шри Ауробиндо или Путешествие сознания. - Л., 1989.

5. Семенова С.Г. Паломник в будущее. Пьер Тейяр де Шарден. - СПб., 2009.

6. Шри Ауробиндо Гхош. Человеческий цикл. - Казань, 1992.

Кіхно О.В. Ідея Суб ’єктивної доби у соиіальній філософії Шрі Ауробіндо.

У статті запропонований аналіз концепції Суб'єктивної доби у соціальній філософії Ауробіндо. Ауробіндо стверджує що відкриття індивідуальним вільним розумом універсальних законів щодо яких індивід є мало не побічним явищем і які повинні управляти ним і спроба фактично 
управляти громадським життям людства в строгій відповідності з цими законами неминуче ведуть до пригнічення індивідуальної свободи. Замість релігійно-етичного авторитету традиційного суспільства реалізовуватиметься науковий, раціональний або експериментальний критерій. Ауробіндо пише, що у такому разі розвинеться стійка система громадських моральних норм і традицій і утвердиться своєрідне соціалістичне вчення, в істинності якого нікому не буде дозволено засумніватися практично i, ймовірно, навіть теоретично, оскільки подібні сумніви можуть потрясти або навіть підірвати систему. 3 іншого боку, існують історичні сили, які можуть присікти такий розвиток або змінити його характер раніше, ніж він досягне свого погрозливого завершення. Стаття розглядає соціальні ідеї Шрі Ауробіндо у зіставленні з ідеями М.Бердяєва, Д.Андрєєва і Теяра де Шардена.

Ключові слова: Суб'єктивна доба, техніка, біосфера, соціальна доктрина, соціальна еволюція.

Кихно А.В. Идея Субъективного Века в сочиальной философии Шри Ауробиндо.

В статье дается анализ концепции Субъективного Века в социальной философии Ауробиндо. Ауробиндо утверждает, что открытие индивидуальным свободным разумом универсальных законов, по отношению к которым индивид является чугь ли не побочным явлением, и которые неизбежно должны управлять им, и попытка фактически управлять общественной жизнью человечества в строгом соответствии с этими законами неминуемо ведут к подавлению индивидуальной свободы. Вместо религиозноэтического авторитета традиционного общества будет реализовываться научный, рациональный или экспериментальный критерий. Ауробиндо пишет, что в таком случае разовьется устойчивая система общественных моральных норм и традиций и утвердится своеобразное социалистическое учение, в истинности которого никому не будет позволено усомниться практически и, вероятно, даже теоретически, поскольку подобные сомнения могут потрясти или даже подорвать систему. С другой стороны, существуют исторические силы, которые, могут пресечь такое развитие или изменить его характер прежде, чем оно достигнет своего угрожающего завершения. Статья рассматривает социальные идеи Шри Ауробиндо в сопоставлении с идеями Н. Бердяева, Д. Андреева и Теяра де Шардена.

Ключевые слова: Субъективный Век, техника, биосфера, социальная доктрина, социальная эволюция.

Kihno A. The idea of Subjective Age in social philosophy of Sri Aurobindo.

The article submits an analysis of social conception of the Subjective Age by Sri Aurobindo. Aurobindo asserts that this discovery by individual free-thought of universal laws of which the individual is almost a by-product and by which 
he must necessarily be governed, this attempt actually to govern the social life of humanity in conscious accordance with the mechanism of these laws seems to lead logically to the suppression of that individual freedom. In place of the religio-ethical sanction there will be a scientific and rational or naturalistic motive and rule. Aurobindo writes that, there would grow up a fixed system of social morality and custom and a body of socialistic doctrine which one could not be allowed to question practically, and perhaps not even intellectually, since that would soon shatter or else undermine the system. On the other hand, there are in operation forces which seem likely to frustrate or modify this development before it can reach its menaced consummation. Aurobindo describes these forces. The article examines Sri Aurobindo's social ideas in comparison with ideas of N. Berdyaev, D. Andreiev and T. de Chardin.

Key words: Subjective Age, technics, biosphere, the social conception, the social evolution. 